University of Nebraska - Lincoln

DigitalCommons@University of Nebraska - Lincoln

2010

Subspecific Status and Population Genetic Structure of Least

Terns (Sternula antillarum) Inferred by Mitochondrial DNA ControlRegion Sequences and Microsatellite DNA

\author{
Hope M. Draheim \\ Michigan State University \\ Mark P. Miller \\ U.S. Geological Survey, mpmiller@usgs.gov \\ Patricia Baird \\ Simon Fraser University \\ Susan M. Haig \\ U.S. Geological Survey, Susan_Haig@usgs.gov
}

Follow this and additional works at: https://digitalcommons.unl.edu/usgsstaffpub

Draheim, Hope M.; Miller, Mark P.; Baird, Patricia; and Haig, Susan M., "Subspecific Status and Population Genetic Structure of Least Terns (Sternula antillarum) Inferred by Mitochondrial DNA Control-Region Sequences and Microsatellite DNA" (2010). USGS Staff -- Published Research. 667.

https://digitalcommons.unl.edu/usgsstaffpub/667

This Article is brought to you for free and open access by the US Geological Survey at DigitalCommons@University of Nebraska - Lincoln. It has been accepted for inclusion in USGS Staff -- Published Research by an authorized administrator of DigitalCommons@University of Nebraska - Lincoln. 


\title{
SUBSPECIFIC STATUS AND POPULATION GENETIC STRUCTURE OF LEAST TERNS (STERNULA ANTILLARUM) INFERRED BY MITOCHONDRIAL DNA CONTROL-REGION SEQUENCES AND MICROSATELLITE DNA
}

\author{
Hope M. Draheim, ${ }^{1,3}$ Mark P. Miller, ${ }^{1,4}$ Patricia Baird, ${ }^{2}$ and Susan M. Haig ${ }^{1}$ \\ ${ }^{1}$ U.S. Geological Survey Forest and Rangeland Ecosystem Science Center, 3200 SW Jefferson Way, Corvallis, Oregon 97331, USA; and \\ ${ }^{2}$ Centre for Wildlife Ecology, Simon Fraser University, Burnaby, British Columbia V5A 1S6, Canada
}

\begin{abstract}
The taxonomic identity of endangered populations of the Least Tern (Sternula antillarum) has long been debated. Their current conservation status provides even more impetus to examine the taxonomic distinctness of these groups. We used rapidly evolving mitochondrial DNA control-region sequences ( 840 base pairs; $n=188$ ) and microsatellite DNA data (7 loci; $n=417)$ to examine genetic structure within and among three subspecies that occur within the United States: California Least Tern (S. a. browni), Interior Least Tern (S. a. athalassos), and Eastern Least Tern (S. a. antillarum). Although significant genetic structure was observed among breeding populations from across the species' range, our data indicated little evidence of genetic structure within traditional subspecific groups. Isolation-by-distance analyses, however, identified subtle patterns that may reflect sex-specific differences in dispersal behavior. Our analyses likewise demonstrated little population subdivision among subspecific groups, which raises questions regarding the taxonomic status of traditionally defined subspecies. Our findings can therefore be used to consider a reevaluation of Least Tern subspecies by the American Ornithologists' Union's Committee on Taxonomy and Nomenclature. We further emphasize the need for studies of range-wide breeding-site fidelity and natal philopatry to better understand interpopulation movements of individuals throughout the annual cycle. Received 9 November 2009, accepted 30 March 2010.
\end{abstract}

Key words: Least Tern, microsatellites, mitochondrial DNA, population structure, Sternula antillarum, subspecies.

\section{Estatus Subespecífico y Estructura Genética Poblacional de Sternula antillarum Inferidos Mediante Secuencias de la Región Control del ADN Mitocondrial y ADN Microsatelital}

RESUMEN.-Por mucho tiempo se ha debatido la identidad taxonómica de las poblaciones en peligro de Sternula antillarum. $\mathrm{Su}$ estatus de conservación actual genera un incentivo aún mayor para examinar la distinción taxonómica de estos grupos. Usamos secuencias de ADN mitocondrial de la región control de rápida evolución (840 pares de bases; $n=188)$ y datos de ADN microsatelital (7 loci; $n=417$ ) para examinar la estructura genética dentro y entre tres subespecies que se encuentran en Estados Unidos: S. $a$. browni, S. a. athalassos y S. a. antillarum. A pesar de que se observó estructura genética entre poblaciones reproductivas dentro del área de distribución de la especie, nuestros datos indicaron poca evidencia de estructura genética entre grupos subespecíficos tradicionales. Los análisis de aislamiento por distancia revelaron patrones que podrían reflejar diferencias sexuales en el comportamiento de dispersión. Nuestros análisis también mostraron poca subdivisión poblacional entre grupos subespecíficos, lo que pone en duda el estatus taxonómico de las subespecies definidas tradicionalmente. Nuestros resultados pueden ser usados para considerar una revaluación de las subespecies de S. antillarum por el comité de taxonomía y nomenclatura de la American Ornithologists' Union. Además, enfatizamos la necesidad de estudios sobre la fidelidad de sitio reproductivo y filopatría natal en toda el área de distribución de la especie para entender mejor los movimientos de individuos entre poblaciones a lo largo de todo el ciclo anual.

THE SUBSPECIES CONCEPT has been extensively applied within avian taxa since Linnaeus first introduced intraspecific classifications in 1753 (American Ornithologists' Union [AOU] 1957). Indeed, ornithologists have spent considerable time and effort refining the concept and debating its utility (Mayr 1942, Amadon 1949, Wilson and Brown 1953, Phillimore and Owens 2006, Winker and Haig 2010). Definitions have varied, from inclusion of geographically distinct natural populations that are not sufficiently different to be considered separate species (Mayr 1942) to more quantitative definitions such as the " $75 \%$ rule," which states that a population

${ }^{3}$ Present address: Department of Zoology, 203 Natural Science Building, Michigan State University, East Lansing, Michigan 48824, USA. ${ }^{4}$ Address correspondence to this author. E-mail: mpmiller@usgs.gov

The Auk, Vol. 127, Number 4, pages 807-819. ISSN 0004-8038, electronic ISSN 1938-4254. @ 2010 by The American Ornithologists' Union. All rights reserved. Please direct all requests for permission to photocopy or reproduce article content through the University of California Press's Rights and Permissions website, http://www.ucpressjournals. com/reprintInfo.asp. DOI: 10.1525/auk.2010.09222 


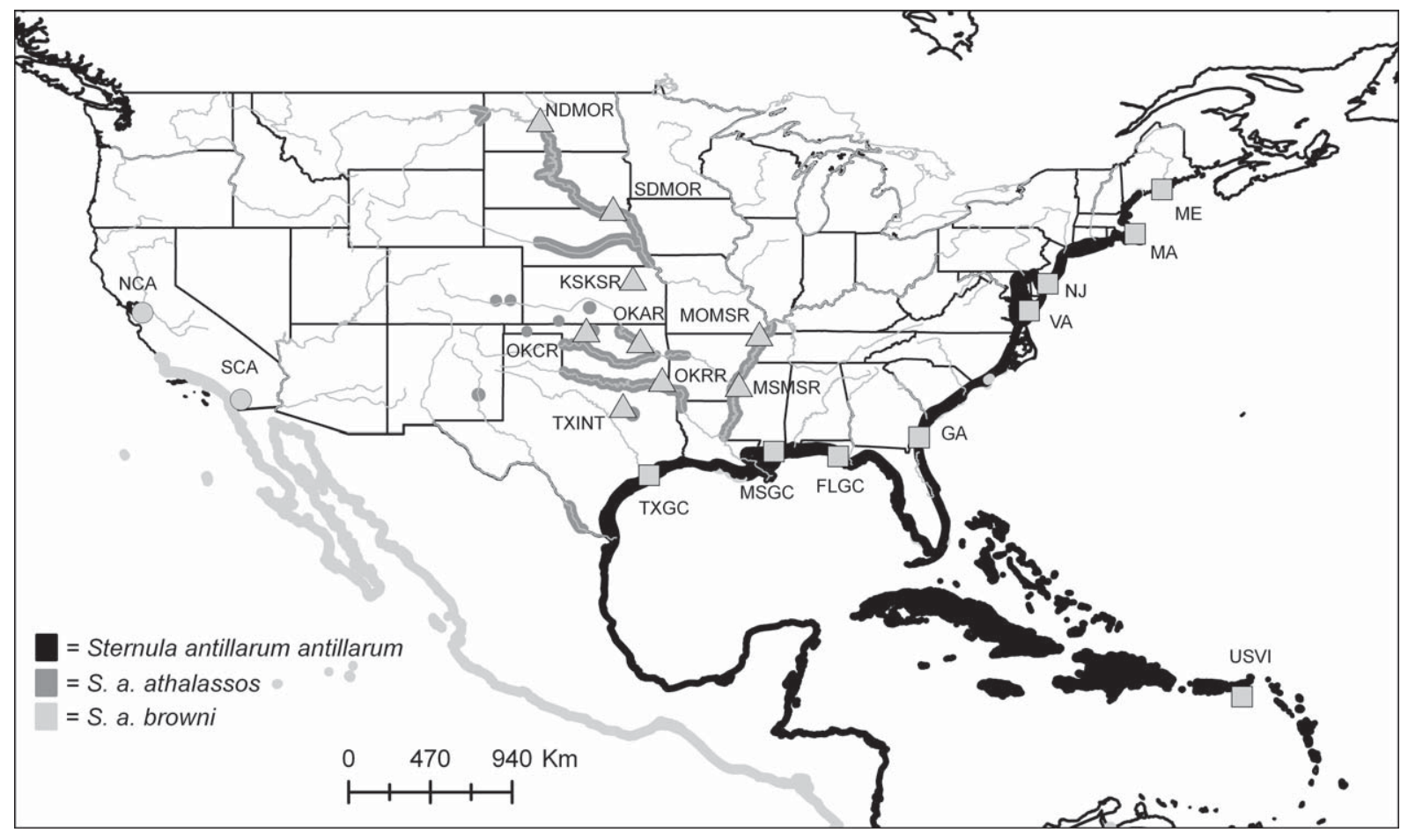

FIG. 1. Map showing the breeding areas of Least Terns included in our study. Breeding areas are listed in Table 1. Breeding distributions of currently recognized subspecies are highlighted. Sampling locations corresponding to the California, Interior, and Eastern subspecies are indicted by circles, triangles, and squares, respectively.

can be described as a separate subspecies only if $75 \%$ of its individuals differ from a previously described subspecies (Amadon 1949).

Today, the debate over taxonomic definitions has widened with the passage of conservation legislation that mandates or allows protection of groups below the species level (e.g., subspecies, evolutionarily significant units, distinct population segments, and more; Haig et al. 2006, Haig and D'Elia 2010). Thus, there can be legal ramifications, depending on how these units are defined. These issues come to the forefront with endangered species such as the Least Tern (Sternula antillarum), various populations of which are listed under the U.S. Endangered Species Act (U.S. Fish and Wildlife Service [USFWS] and National Marine Fisheries Service 1996).

At least five Least Tern subspecies have been described on the basis of morphological characteristics (Thompson et al. 1997). Three U.S. subspecies are recognized by the AOU that correspond to the eastern United States (S. a. antillarum; Lesson 1847), interior United States (S. a. athalassos; Burleigh and Lowery 1942), and California (S. a. browni; Mearns 1916) (AOU 1957; Fig. 1). The taxonomic status of the two subspecies described from Mexico, S. a. mexicana (van Rossem and Hachisuka 1937) and S. a. staebleri (Brodkorb 1940), is uncertain (García and Ceballos 1995, Patten and Erickson 1996).

Recent population counts estimate the breeding population of Least Terns in the United States to be $\sim 85,000$ birds (California, 14,000; Interior, 18,000; Eastern, 53,000) (Marschalek 2005, Lott 2006, and data from the Mid-Atlantic/New England/Maritimes
Regional Working Group and Southeast Regional Working Group [see Acknowledgments]). Although actual numbers are unknown, it is thought that Least Terns were historically abundant throughout their range. During the 20th century, however, the species experienced large population declines as a result of anthropogenic pressures (USFWS 1980, 1990; Burger 1984; Kruse et al. 2001). As a result, the California subspecies is listed as endangered under the U.S. Endangered Species Act (USFWS 1980). The Interior subspecies was not listed as a subspecies because of taxonomic uncertainty at the time of listing; however, the USFWS designated "the populations of Least Terns occurring in the interior of the United States" as endangered (USFWS 1985). The Eastern subspecies is state-listed as threatened or endangered in most states in which it occurs (USFWS 1980, 1990).

The need to clarify appropriate taxonomic units for Least Terns led to two studies that revealed little genetic differentiation among traditional Least Tern subspecies. Using 12 polymorphic allozyme loci, Thompson et al. (1992) found no genetic differentiation between the Interior $(n=11)$ and Eastern subspecies $(n=$ 11). Subsequently, Whittier et al. (2006) used single-strand conformation polymorphism analyses to examine variation in the mitochondrial DNA (mtDNA) cytochrome- $b$ region and two nuclear introns among the U.S. subspecies (Eastern, $n=17$; Interior, $n=$ 22; California, $n=14$ ). All genetic markers revealed low variability (three mtDNA haplotypes; three alleles at one nuclear intron, one allele at the second). The variable intron indicated some genetic differentiation between the California and Interior breeding areas $\left(F_{\mathrm{ST}}=0.11\right)$, but the pattern was not corroborated by the 
TABLE 1. Sample sizes and genetic diversity parameters ${ }^{a}$ for mtDNA control region (840 bp) and seven microsatellite loci in Least Terns (Sternula antillarum). Significant values for $R_{2}$ and $F_{\mathrm{S}}$ statistics $(P<0.05)$ are followed by asterisks.

\begin{tabular}{|c|c|c|c|c|c|c|c|c|c|c|c|c|}
\hline \multirow[b]{2}{*}{ Subspecies } & \multirow[b]{2}{*}{ Breeding area } & \multirow[b]{2}{*}{ County and state } & \multicolumn{6}{|c|}{ MtDNA } & \multicolumn{4}{|c|}{ Microsatellites } \\
\hline & & & $n$ & $\begin{array}{l}\text { Number of } \\
\text { haplotypes }\end{array}$ & (h) & $(\pi)$ & $F_{\mathrm{S}}$ & $R_{2}$ & $n$ & $A$ & $H_{\mathrm{E}}$ & $H_{\mathrm{O}}$ \\
\hline \multicolumn{3}{|c|}{ California (S. a. browni) } & 20 & 7 & 0.76 & 0.0021 & -1.584 & 0.118 & 50 & $3.57(3.57)$ & 0.464 & 0.474 \\
\hline & $\mathrm{NCA}$ & Alameda, California & 10 & 6 & 0.89 & 0.0029 & -1.363 & 0.174 & 26 & $3.29(2.77)$ & 0.457 & 0.472 \\
\hline & SCA & San Diego, California & 10 & 4 & 0.53 & 0.0010 & $-1.345^{*}$ & 0.166 & 24 & $3.29(2.80)$ & 0.472 & 0.477 \\
\hline \multicolumn{3}{|c|}{ Interior (S. a. athalassos) } & 85 & 28 & 0.95 & 0.0046 & $-12.811^{*}$ & 0.080 & 185 & $5.43(4.38)$ & 0.500 & 0.495 \\
\hline & NDMOR & McLean, North Dakota & 8 & 6 & 0.89 & 0.0026 & $-2.444^{*}$ & $0.141^{*}$ & 20 & $3.86(3.25)$ & 0.508 & 0.442 \\
\hline & SDMOR & Yankton, South Dakota & 9 & 7 & 0.94 & 0.0054 & -1.453 & 0.178 & 30 & $3.57(3.08)$ & 0.508 & 0.538 \\
\hline & KSKSR & Pottawatomie, Kansas & 10 & 7 & 0.91 & 0.0048 & -1.244 & 0.138 & 18 & $3.29(3.02)$ & 0.516 & 0.549 \\
\hline & MOMSR & New Madrid, Missouri & 9 & 8 & 0.97 & 0.0034 & $-4.550^{*}$ & $0.111^{*}$ & 14 & $3.71(3.26)$ & 0.512 & 0.510 \\
\hline & OKCR & Woods, Oklahoma & 10 & 9 & 0.98 & 0.0058 & $-3.696^{*}$ & 0.139 & 14 & $3.57(3.23)$ & 0.498 & 0.422 \\
\hline & OKAR & Tulsa, Oklahoma & 9 & 7 & 0.94 & 0.0054 & -1.453 & 0.175 & 35 & $4.14(3.2)$ & 0.497 & 0.473 \\
\hline & OKRR & McCurtain, Oklahoma & 10 & 9 & 0.98 & 0.0067 & $-3.220^{*}$ & 0.145 & 18 & $3.71(3.10)$ & 0.458 & 0.521 \\
\hline & TXINT & Dallas, Texas & 10 & 6 & 0.89 & 0.0028 & -1.459 & 0.153 & 17 & $3.43(2.97)$ & 0.474 & 0.487 \\
\hline & MSMSR & Bolivar, Mississippi & 10 & 7 & 0.87 & 0.0028 & $-2.815^{*}$ & $0.098^{*}$ & 19 & $3.86(3.18)$ & 0.506 & 0.506 \\
\hline \multicolumn{3}{|c|}{ Eastern (S. a. antillarum) } & 83 & 44 & 0.96 & 0.0057 & $-25.590^{*}$ & 0.058 & 182 & $6.14(4.94)$ & 0.494 & 0.480 \\
\hline & ME & Knox, Maine & 7 & 4 & 0.81 & 0.0048 & -1.247 & 0.294 & 21 & $3.71(2.82)$ & 0.453 & 0.478 \\
\hline & MA & Barnstable, Massachusetts & 11 & 8 & 0.93 & 0.0054 & -1.724 & 0.167 & 61 & $4.43(3.00)$ & 0.477 & 0.457 \\
\hline & NJ & Cape May, New Jersey & 10 & 8 & 0.96 & 0.0065 & -1.760 & 0.158 & 12 & $3.57(3.24)$ & 0.500 & 0.500 \\
\hline & VA & Accomack, Virginia & 9 & 9 & 1.00 & 0.0048 & $-5.661^{*}$ & 0.144 & 10 & $3.29(3.07)$ & 0.467 & 0.500 \\
\hline & GA & Glenn, Georgia & 8 & 8 & 1.00 & 0.0069 & $-3.497^{*}$ & 0.124 & 8 & $3.57(3.57)$ & 0.564 & 0.554 \\
\hline & USVI & St. Croix, Virginia & 10 & 7 & 0.91 & 0.0060 & -0.716 & 0.145 & 24 & $4.00(3.32)$ & 0.532 & 0.537 \\
\hline & FLGC & Bay, Florida & 8 & 8 & 1.00 & 0.0061 & $-3.381^{*}$ & 0.160 & 15 & $3.29(2.93)$ & 0.464 & 0.411 \\
\hline & MSGC & Harrison, Mississippi & 10 & 8 & 0.93 & 0.0052 & -2.377 & 0.150 & 16 & $3.57(3.10)$ & 0.503 & 0.527 \\
\hline & TXGC & Brazoria, Texas & 10 & 8 & 0.96 & 0.0058 & -2.063 & $0.112^{*}$ & 15 & $3.71(3.32)$ & 0.503 & 0.440 \\
\hline
\end{tabular}

a Number of individuals sampled $(n)$, haplotype diversity $(h)$, number of haplotypes, nucleotide diversity $(\pi)$, mean number of alleles per locus $(A ;$ rarefied estimate accounting for different sample sizes provided in parentheses), expected heterozygosity $\left(H_{\mathrm{E}}\right)$, and observed heterozygosity $\left(H_{\mathrm{O}}\right)$.

mtDNA data $\left(F_{\mathrm{ST}}=0\right)$. Sample sizes were small in both studies, but each concluded that traditional subspecific distinctions were unresolved. Thus, we conducted rigorous sampling and applied rapidly evolving loci (mtDNA control region and microsatellites) to more definitively assess genetic variability and population genetic structure in Least Terns across their North American range. Our primary objectives were to (1) characterize range-wide breedingsite genetic structure and diversity patterns and (2) provide a comprehensive evaluation of Least Tern subspecies designations.

\section{Methods}

Sampling.-We obtained 417 Least Tern samples from several tissue sources: blood from live specimens, salvaged carcasses, and embryos from collected eggs. To ensure that tissues were representative of local breeding areas, sampling was limited to breeding adults and young-of-year fledglings collected at the breeding area before individuals moved to migration staging areas. Eight to 61 samples were collected from each of 20 breeding areas throughout the Least Tern's breeding range (Fig. 1 and Table 1). Coastal breeding areas were defined as groups of individual samples collected within a breeding colony or collected from multiple adjacent colonies. Breeding areas along interior rivers were defined as a group of individual samples collected within 50 river miles. Additionally, breeding areas that occurred within the described geographic ranges of the traditional subspecies were grouped accordingly (Table 1).

DNA extraction, marker isolation, and amplification.-DNA was obtained from samples using standard phenol-chloroform extractions as previously described (Haig et al. 2004). Initially, a 1,800-base-pair (bp) segment containing the NADH dehydrogenase subunit 6 gene (ND6) and control region of the mtDNA genome was amplified and sequenced in 12 specimens by long polymerase chain reaction (PCR; GeneAmp XL PCR Kit; Roche Molecular Systems, Branchburg, New Jersey) using conserved mtDNA primers L16087 (5'-TGGTCTTGTAARCCAAARANYGAAG-3; Desjardins and Morais 1990) and H1248 (5'-CATCTTCAGTGCCATGCTTT-3'; Tarr 1995). Sequences were aligned with known NADH dehydrogenase subunit 6 gene (ND6) and control-region sequences of a variety of tern and gull (i.e., Charadriiformes) species from GenBank to confirm that the sequence was mitochondrial and not a nuclear homolog. Likewise, the transition:transversion ratio of the sequence was 38:6, which suggests a strong transition bias as expected in mtDNA (Wakeley 1996). Our alignment was used to design new internal primers LETE 70 L (5'-ATACGCTCACATGCACCT-3') and LETE $1000 \mathrm{H}$ (5'-ACTGTCGTTGACGTATAACAA-3') that amplified 840 bp of the Least Tern mtDNA control region. Primers annealed $\sim 90$ bp downstream from the $5^{\prime}$ end of control region domain I and $\sim 50$ bp upstream of the AC repeat at the $3^{\prime}$ end of domain III. For subsequent PCR reactions, a total reaction volume of $50 \mu \mathrm{L}$ was used with the following concentrations: $10 \mathrm{mM}$ Tris$\mathrm{HCl}$ at $\mathrm{pH} 8.3,50 \mathrm{mM} \mathrm{KCl}, 0.001 \%$ gelatin, $3.5 \mathrm{mM} \mathrm{MgCl}_{2}, 100 \mu \mathrm{m}$ of each dNTP, $0.2 \mu \mathrm{m}$ of each primer, $50-100 \mathrm{ng}$ of template, and 1.5 U AmpliTaq Gold Polymerase (Perkin Elmer, Waltham, Massachusetts). The following parameters were used for amplifications: 2 min denaturation at $93^{\circ} \mathrm{C}$, followed by 35 cycles of $30 \mathrm{~s}$ at $93^{\circ} \mathrm{C}$, annealing at $50^{\circ} \mathrm{C}$ for $30 \mathrm{~s}$, and elongation at $72^{\circ} \mathrm{C}$ for $1 \mathrm{~min}$. A final 10 -min period of elongation at $72^{\circ} \mathrm{C}$ followed the last cycle. 
The PCR amplicons were visualized on 1\% agarose gels and subsequently cleaned and concentrated by centrifugation dialysis using Microcon 30,000 MW cutoff filters (Amicon Bioseparations, Bedford, Massachusetts). Complete bidirectional sequences were obtained using primers LETE 70 L, LETE $1000 \mathrm{H}$, LETE $560 \mathrm{H}\left(5^{\prime}\right.$ CATAACTTGATTAATCCTTTCAAC-3'), and LETE $690 \mathrm{~L}$ (5'CTCGAATACCTCAATGAGAC-3'). Sequences were generated using ABI Prism Big Dye Terminator Cycle Sequencing chemistry on an ABI 3730 DNA sequencer located in the Central Services Laboratory at Oregon State University. Sequences were aligned using BIOEDIT, version 7.0.5 (Hall 1999), and archived in GenBank (accession nos. EU268123-EU268190). In total, 188 specimens were used in mtDNA analyses (Table 1).

We used seven variable microsatellite loci in our analyses: Hbau4 (PCR annealing temperature $T \mathrm{~A}=55^{\circ} \mathrm{C}$; J. R. Gust et al. unpubl. data); K6, $\mathrm{K} 16\left(\mathrm{TA}=53^{\circ} \mathrm{C}\right.$; Tirard et al. 2002); RBG13 $\left(T \mathrm{~A}=53^{\circ} \mathrm{C}\right)$; RBG18, RBG27 $\left(\mathrm{TA}=50^{\circ} \mathrm{C}\right.$; Given et al. 2002); and SDAAT $27\left(T A=58^{\circ} \mathrm{C}\right.$; Szczys et al. 2005). DNA was amplified using a PCR profile with the following steps: initial denaturation for $5 \mathrm{~min}$ at $94^{\circ} \mathrm{C}$, followed by 29 cycles of $30 \mathrm{~s}$ at $94^{\circ} \mathrm{C}, 30 \mathrm{~s}$ at the specified annealing temperature, $60 \mathrm{~s}$ at $72^{\circ} \mathrm{C}$, then an additional 10 -min extension step at $72^{\circ} \mathrm{C}$. Ten-microliter reactions were prepared using 50-100 ng of DNA in $10 \mathrm{mM}$ Tris- $\mathrm{HCl} ; 50 \mathrm{mM} \mathrm{KCl}$; $2.0 \mathrm{mM} \mathrm{MgCl} ; 0.25 \mathrm{mM}$ of each dNTP; $15 \mu \mathrm{m}$ of each primer; and 0.5 units of Taq polymerase (Promega, Madison, Wisconsin). Amplified products were sized on an ABI 3730 automated DNA sequencer at Oregon State University's Central Services Laboratory. Genotype analysis was performed using the software applications GENESCAN ANALYSIS, version 3.2, and GENOTYPER, version 2.5 (Applied Biosystems, Carlsbad, California). A total of 417 individuals were used for microsatellite analyses (Table 1).

Range-wide genetic structure and diversity.-We used ARLEQUIN, version 3.11 (Excoffier et al. 2005), to calculate haplotype diversity $(h)$, the probability that two randomly chosen individuals have different haplotypes; and nucleotide diversity $(\pi)$, the average pairwise nucleotide differences for control-region haplotypes at each breeding area of the traditional subspecies. Fu's $F_{\mathrm{S}}$ (Fu 1997) and the $R_{2}$ statistic of Ramos-Onsins and Rozas (2002) were also used to identify the signal of historical population expansions. $F_{\mathrm{S}}$ and $R_{2}$ have been identified as having the greatest power for identifying these patterns (Ramos-Onsins and Rozas 2002). ARLEQUIN was used for $F_{\mathrm{S}}$ calculations, whereas DNASP, version 5.0 (Rozas et al. 2003), was used to calculate $R_{2}$. In both cases, the significance of observed values was inferred through the use of 1,000 coalescent-based simulations.

The program GDA, version 1.1 (Lewis and Zaykin 2001), was used to quantify microsatellite genetic diversity in each breeding area and within each traditional subspecies grouping using mean number of alleles $(A)$, observed heterozygosity $\left(H_{\mathrm{O}}\right)$, and expected heterozygosity $\left(H_{\mathrm{E}}\right)$ for each locus and over all loci. The program HP-RARE (Kalinowski 2005) was used to obtain rarefied estimates of allelic diversity within these units to better account for sample-size variation. GDA was also used to identify deviations from Hardy-Weinberg proportions and to test for linkage disequilibrium between pairs of loci within each breeding area. In HardyWeinberg tests, $P$ values over loci were combined and evaluated using the $Z$-transform test (Whitlock 2005) to obtain a composite result for each breeding area. The program BOTTLENECK was used to detect recent population bottlenecks within each breeding area (Cornuet and Luikart 1996). Analyses were run under the two-phase model (TPM) assuming a TPM variance of 30 and with $70 \%$ of mutations corresponding to a pure stepwise mutational model. Given the number of loci examined and sample sizes within breeding areas, we note that these analyses may have limited power for our data set (Cornuet and Luikart 1996). However, given the lack of power, we may possibly expect to hold more confidence in any significant result that is identified, especially if other analyses can possibly corroborate inferences made in these analyses. Therefore, we used BOTTLENECK to perform an independent test that screened for skewed allele-frequency distributions in each breeding area, which also provides heuristic evidence of the effects of prior bottleneck events (Luikart et al. 1998).

We quantified and tested for genetic structure and differentiation among breeding areas using the maximum-likelihood estimator of $D$ described in Jost (2008). Most conventional $F$ statistics variants have upper bounds that are constrained by underlying levels of genetic diversity (Hedrick 2005). These issues may make comparisons across marker types or study systems problematic, because higher-diversity loci will generate lower overall $F_{\mathrm{ST}}$ values-even in cases where populations are completely differentiated. $D$ does not suffer from these issues (Jost 2008) and consistently represents differentiation of samples as values that fall along the continuous interval from zero to unity. Thus, global and pairwise estimates of $D$ among all 20 breeding areas were obtained separately for microsatellite $\left(D_{\text {mic }}\right)$ and mtDNA data $\left(D_{\text {mit }}\right)$. Comparable global differentiation measures were likewise obtained for breeding areas within each traditional subspecies. For the microsatellite data, multilocus estimates of $D_{\text {mic }}$ were constructed using an approximation to the harmonic mean of locus-specific values, calculated as

$$
\bar{D}_{\text {mic }}=1 /\left[\left(1 / D_{\mathrm{A}}\right)+\sigma_{D}^{2}\left(1 / D_{\mathrm{A}}\right)^{3}\right]
$$

where $D_{\mathrm{A}}$ and $\sigma_{D}^{2}$ are the arithmetic mean and variance, respectively, of the locus-specific $D$ values (A. Chao pers. comm.). $P$ values for single-locus and multilocus $D$ values were obtained through a randomization procedure based on 10,000 randomization replicates. In each replicate, individuals (and their respective genotypes or mtDNA haplotypes) were randomly allocated to breeding areas while keeping the sample sizes of breeding areas coincident with the original data. $P$ values were ultimately obtained as the proportion of randomized data sets producing values of $D$ as large as or larger than the original $D$ values. Comparable global estimates of $D$ were also obtained for each traditional subspecies. All calculations for $D$ were performed using a short computer program written by M.P.M. Mantel tests (Mantel 1967) based on 5,000 randomization replicates were used to quantify correlations between pairwise $D_{\text {mic }}$ and $D_{\text {mit }}$ values of breeding areas using the program NT-SYS, version 2.10 (Exeter, Setauket, New York).

Mantel tests were also used to identify isolation-by-distance patterns by assessing the correlation between $D$ values and the logarithm of geographic distances between breeding areas. These analyses were performed separately for the mtDNA and microsatellite data and were likewise also performed (1) across the full range of Least Terns in the United States and (2) separately within the Eastern and Interior subspecies groups. Mantel tests were not 
possible within the California subspecies group because of the small number of breeding sites $(n=2)$ examined.

Genetic differences among traditional subspecies.-We used three approaches to examine differentiation among the three traditionally defined Least Tern subspecies. First, relationships among Least Tern control-region haplotypes were inferred by estimating a statistical haplotype network with 95\% parsimonious connections using the program TCS, version 1.13 (Clement et al. 2000). If traditional subspecies are valid, we expected to observe strong associations between haplotype lineages and sets of birds collected within the ranges of the three traditional subspecies groups. Second, we used STRUCTURE, version 2.2 (Pritchard et al. 2000), in conjunction with our microsatellite data to infer the number of Least Tern genetic clusters $(K)$. We performed 10 independent runs for each value of $K=1-8$ using $3^{*} 10^{6}$ iterations after a burn-in period of $2 * 10^{5}$ steps. Analyses were performed using the correlated-allele-frequencies model and admixture model implemented in the program. The most likely number of clusters was determined by identifying values of $K$ that produced the highest average log likelihood values. If genetic structure was largely congruent with traditional subspecies definitions, then we expected to observe the highest likelihood values for the $K=3$ case and likewise expected to see the majority of individuals from each of the three subspecies assigned to cohesive genetic clusters. Finally, global and pairwise estimates of Jost's $D$ were calculated as described above using traditionally defined subspecies as the operational unit of interest. The significance of these values was determined using 10,000 randomization replicates. As with our other analyses, we expected our results to reflect levels of divergence that were consistent with low gene flow among groups.

\section{Results}

Genetic structure and diversity.-Sixty-seven haplotypes were observed among the 188 sampled individuals, 10 of which were shared among traditional subspecies (Table 2). Thirty-six haplotypes were observed only once, reflecting a high underlying level of mtDNA diversity. Control-region sequences (840 bp) were characterized by 44 polymorphic sites, and no insertions or deletions were present. Observed nucleotide composition (A, 23.69\%; C, $28.20 \%$; T, 30.82\%; G, 17.29\%) was similar to that of other charadriiform species (Wenink et al. 1994, Buehler and Baker 2003, Funk et al. 2007). Within-breeding-area haplotype diversity was high (mean $\pm \mathrm{SD}=0.915 \pm 0.103$ ) and ranged from 0.53 (SCA) to 1.0 (FLGC, GA, and VA) (Table 1).

Tests for population expansions revealed significant (at the $\alpha=0.05$ level) negative values of $F_{\mathrm{S}}$ in 9 of the 20 breeding areas examined, whereas significant $R_{2}$ statistics were observed at four breeding areas (Table 1). In three of the four cases involving significant $R_{2}$ values, the corresponding values of $F_{\mathrm{S}}$ were also significant. Across regions, the signal of population expansions was identified within the Interior and Eastern groups, but only from tests using $F_{\mathrm{S}}$ as an indicator (Table 1 ).

The total number of microsatellite alleles per locus ranged from 3 (locus K6) to 11 (locus K16). Genetic diversity was similar among breeding areas (Table 1), with the mean number of alleles per locus ranging from 3.3 (NCA, SCA, VA, and FLGC) to 4.4 (MA). Rarefied estimates of allelic richness were also similar

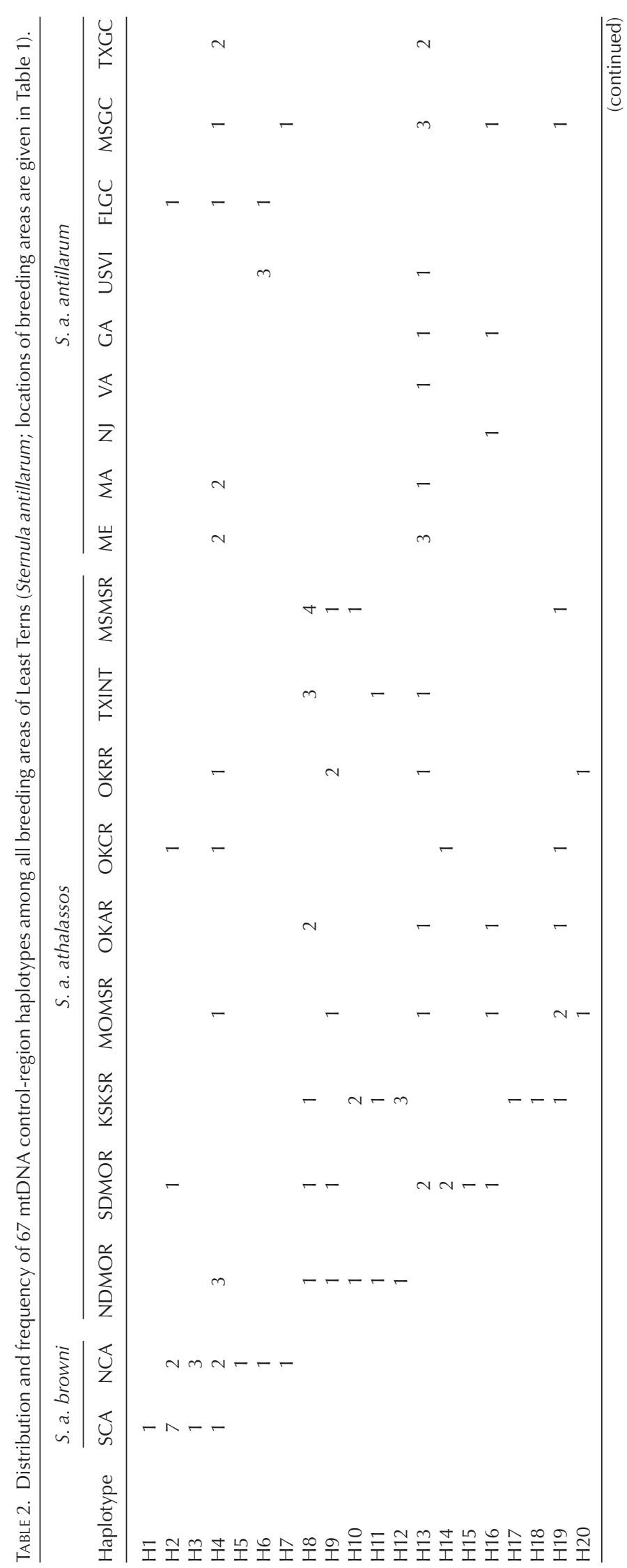




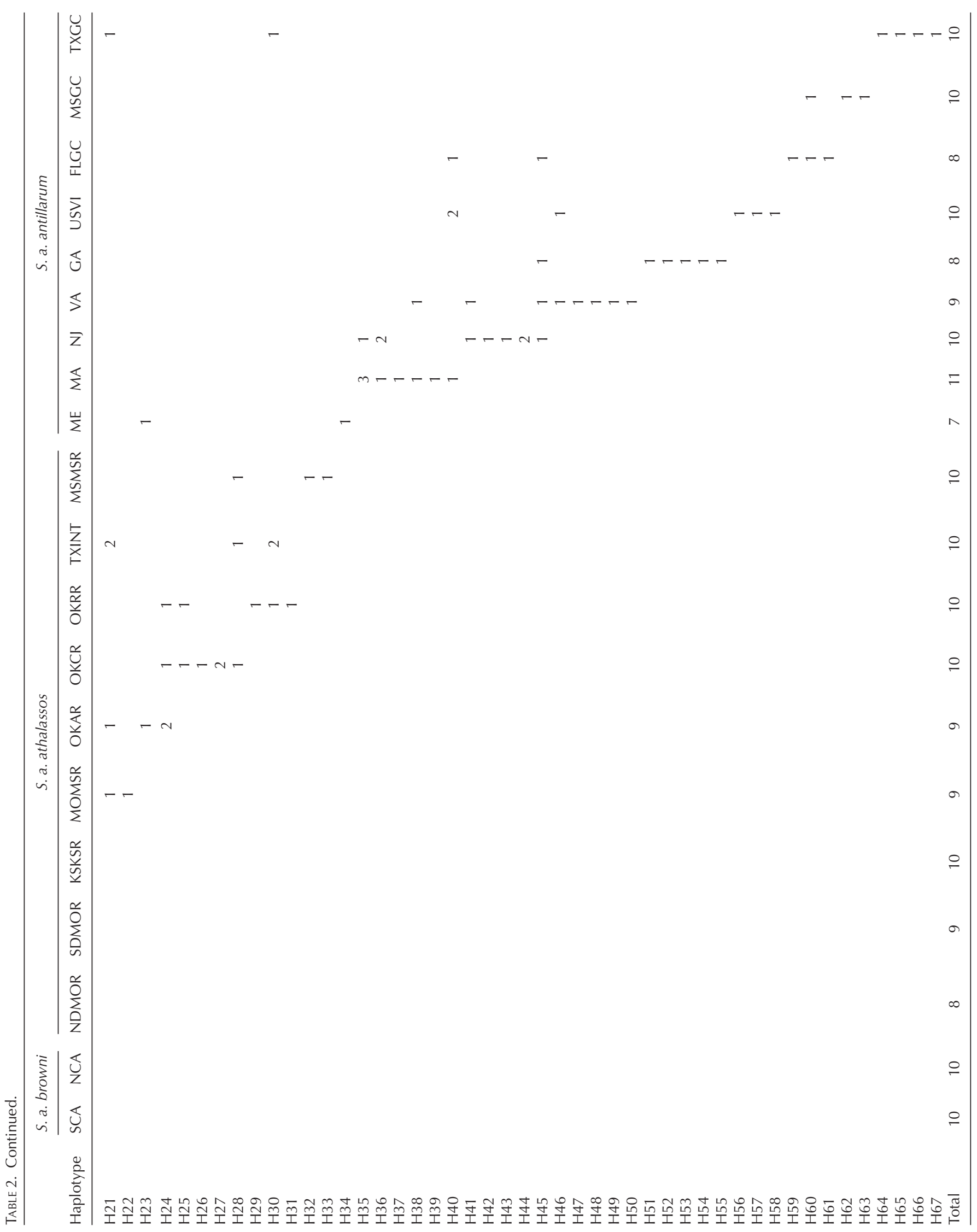


TABLE 3. Indicators of genetic differentiation $(D)$ and associated $P$ values for different hierarchical levels and subsets of the genetic data set for Least Terns. The number of significant locus-specific values of $D$ (out of 7 total) observed for the microsatellite data is also provided.

\begin{tabular}{|c|c|c|c|c|c|}
\hline & \multirow{2}{*}{$\begin{array}{l}\text { Number of significant } \\
\text { loci at } \alpha=0.05 \text { level }\end{array}$} & \multicolumn{2}{|c|}{ Microsatellite data } & \multicolumn{2}{|c|}{ Mitochondrial data } \\
\hline & & $D$ & $P$ & $D$ & $P$ \\
\hline All breeding areas & 4 & 0.038 & $<0.001$ & 0.835 & $<0.001$ \\
\hline Interior breeding areas & 0 & 0.026 & 0.090 & 0.730 & 0.038 \\
\hline Eastern breeding area & 1 & 0.027 & 0.342 & 0.767 & 0.101 \\
\hline California breeding areas & 0 & 0.008 & 0.581 & 0.472 & 0.063 \\
\hline All three subspecies & 6 & 0.023 & $<0.001$ & 0.831 & $<0.001$ \\
\hline California vs. Interior & 5 & 0.020 & $<0.001$ & 0.873 & $<0.001$ \\
\hline California vs. Eastern & 5 & 0.018 & $<0.001$ & 0.859 & $<0.001$ \\
\hline Interior vs. Eastern & 4 & 0.021 & $<0.001$ & 0.620 & $<0.001$ \\
\hline
\end{tabular}

${ }^{a}$ Number of significant loci at $\alpha=0.05$ level.

among breeding areas (range: 2.8-3.6). Average observed and expected heterozygosity within breeding areas ranged from 0.411 and 0.453 to 0.554 and 0.564 , respectively (Table 1 ). According to our combined analyses over loci, no significant deviations from Hardy-Weinberg genotypic proportions were observed within any breeding area $(P>0.2)$. Fifteen significant tests for linkage disequilibrium were observed at the $\alpha=0.05$ level among the 420 tests performed $(3.5 \%$; 21 locus combinations per breeding area $\times$ 20 breeding areas $=420$ total tests), a result that could have been observed by chance alone. These significant tests were also evenly distributed among locus pairs and populations, which further indicated the absence of linkage disequilibrium. The program BOTTLENECK detected a significant excess of heterozygosity within the SDMOR and KSKSR breeding areas $(P=0.004$ and $P=0.039$, respectively). However, these analysis results may be a chance outcome from multiple tests, given that samples from both locations (and all other breeding areas) also demonstrated normal L-shaped allele frequency distributions typical of nonbottlenecked populations (Luikart et al 1998). Furthermore, $P$ values from both of these tests were nonsignificant after sequential Bonferroni corrections.

Our analyses of population structure identified multiple trends. Numerical values of $D_{\text {mit }}$ were generally an order of magnitude larger (or more) than comparable values of $D_{\text {mic }}$ (Table 3 and Appendix), which reflects the overall high observed haplotype diversity and low degree of allele sharing between groups (Table 2). Nonetheless, similar general patterns were observed between the microsatellite and mtDNA sequence data sets. For example, the global matrices of $D_{\text {mic }}$ and $D_{\text {mit }}$ calculated between all pairwise combinations of breeding areas showed loose, but significant, correlations with one another $(r=0.279, P<0.001$; Appendix). Likewise, with one exception, the significance of $D_{\text {mit }}$ and $D_{\text {mic }}$ calculated for different partitions and hierarchical levels in the data set were similar (Table 3). Specifically, both data sets indicated significant genetic structure among the 20 breeding areas investigated $\left(D_{\text {mit }}=0.835, P<0.001 ; D_{\text {mic }}=0.038, P<\right.$ 0.001 ). However, analyses based solely on each traditional subspecies provided slightly different results. No significant differentiation was observed between the two breeding areas representing the California subspecies $\left(D_{\text {mic }}=0.008, P=0.581 ; D_{\text {mit }}=0.472\right.$,
$P=0.063)$. The Eastern subspecies demonstrated similar trends $\left(D_{\text {mic }}=0.027, P=0.342 ; D_{\text {mit }}=0.767, P=0.101\right)$. Within the Interior subspecies, the microsatellite data also revealed no significant structure $\left(D_{\text {mic }}=0.026, P=0.090\right)$. However, $D_{\text {mit }}$ for the Interior subspecies, though numerically similar to that observed among Eastern breeding areas, was significant at the $\alpha=0.05$ level $\left(D_{\text {mit }}=\right.$ $0.730, P=0.038$ ).

Mantel tests designed to identify correlations of genetic and geographic distances between pairs of breeding sites indicated that significant spatial genetic structure exists within Least Terns (Table 4). Across all 20 breeding areas investigated, significant correlations between genetic and geographic distances were observed for microsatellite data and mtDNA sequence data (Table 4). However, different results were obtained when we analyzed subsets of breeding areas that encompassed the Interior and Eastern groups. In this case, microsatellite analyses identified isolationby-distance patterns within regions (Table 4). However, mtDNA analyses identified no significant spatial structure (Table 4).

Analyses of traditional subspecies.-Although 57 controlregion haplotypes were restricted to single traditional subspecies (Table 2), the mtDNA haplotype network revealed no definitive associations between haplotype lineages, geography, or traditional subspecies definitions (Fig. 2). Some phylogenetic clustering of haplotypes was observed within the California traditional subspecies (Fig. 2), but these haplotypes were also generally shared with the other two traditional subspecies groups.

According to STRUCTURE analyses of the microsatellite data, the highest average log-likelihood value $(-5,624.42)$ was

TABLE 4. Results of Mantel tests that assessed the significance of correlations between pairwise values of $D$ and the logarithm of geographic distances between breeding areas of Least Terns.

\begin{tabular}{lrrrrrr}
\hline & \multicolumn{2}{c}{ Microsatellite } & & \multicolumn{2}{c}{ Mitochondrial } \\
\cline { 2 - 3 } & $r$ & $P$ & & $r$ & $P$ \\
\hline All breeding areas & 0.385 & $<0.001$ & & 0.394 & 0.002 \\
Interior breeding areas only & 0.517 & 0.011 & & -0.190 & 0.845 \\
Eastern breeding area only & 0.368 & 0.049 & & -0.007 & 0.471 \\
\hline
\end{tabular}




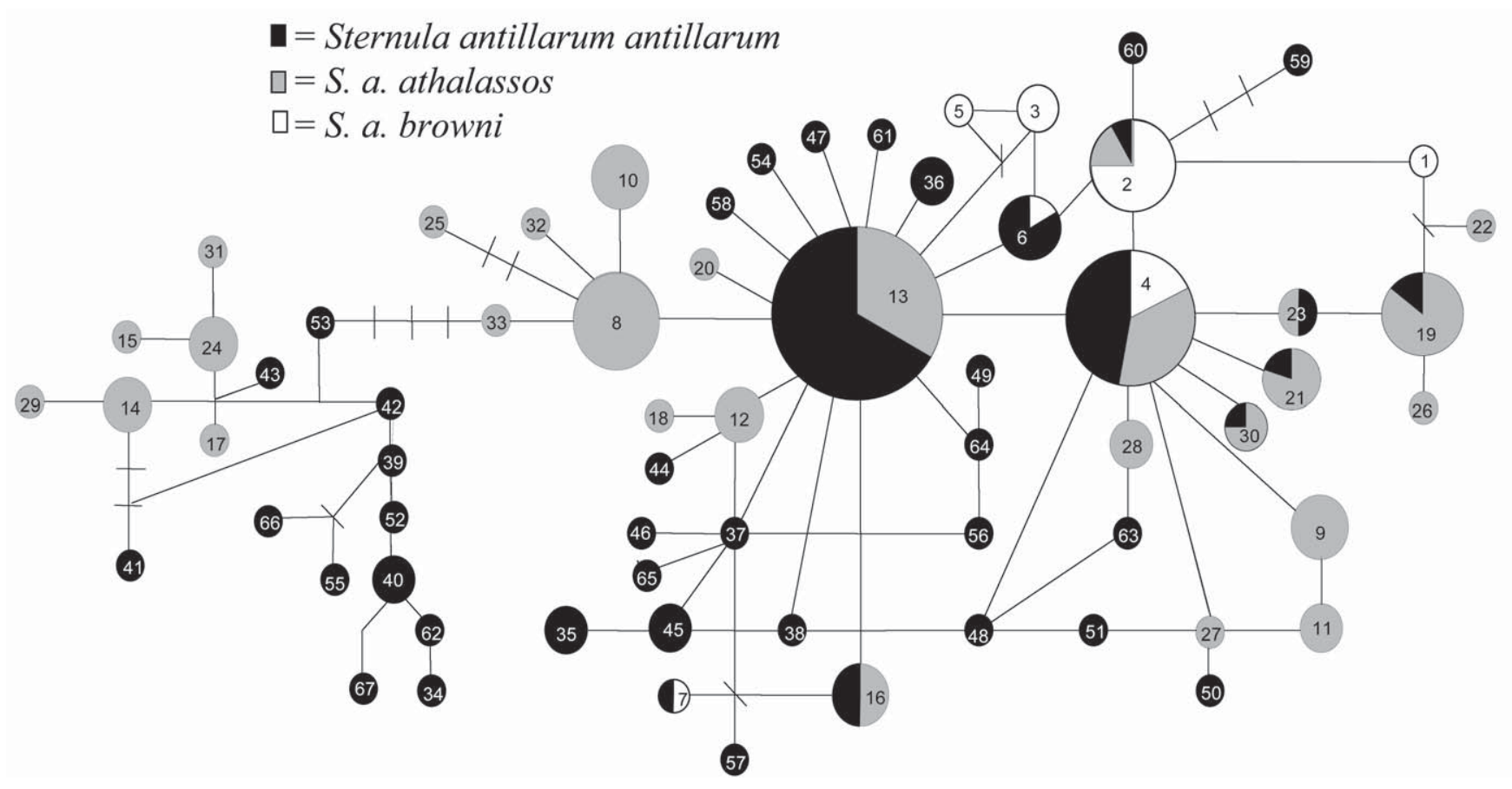

FIG. 2. The statistical 95\% parsimony network generated by the program TCS, based on mtDNA control-region haplotypes of Least Terns. Circle sizes are proportional to the number of individuals that share the haplotype (frequencies of each haplotype are given in Table 2). Shading refers to the proportion of samples that came from a traditional subspecies designation: California Least Tern haplotypes are shown in white, Interior Least Tern haplotypes in gray, and Eastern Least Tern haplotypes in black. Dashes represent inferred haplotypes.

observed for $K=1$ (Fig. 3), which suggests that there was no strong clustering of individuals into traditionally defined subspecies groups. We further note that for the $K=2$ and $K=3$ cases, assignment probabilities of individuals to clusters were generally on the order of 0.5 (for $K=2$ ) or 0.333 (for $K=3$ ) and also showed no associations with traditional subspecies groups. By contrast, however, global indicators of subspecies differentiation were highly significant $\left(D_{\text {mit }}=0.831, P<0.001 ; D_{\text {mic }}=0.033, P<0.001\right)$ when traditional subspecies groups were used as the operational unit of interest (Table 3). Comparable patterns were identified in pairwise

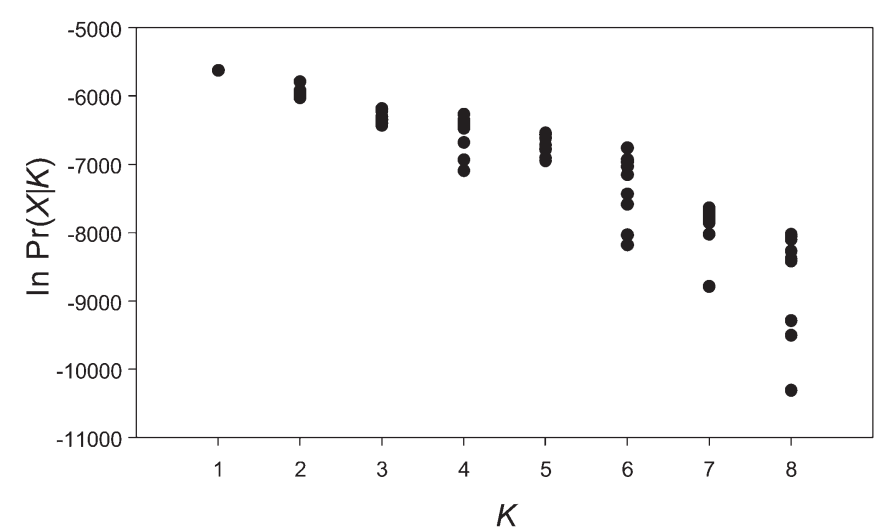

FIG. 3. Results of analyses of 417 Least Terns using the program STRUCTURE. Analyses suggested that a single cluster $(K=1)$ was most likely, given data from the seven microsatellite loci examined. comparisons between subspecies groups (Table 3). However, the magnitude of differentiation observed at this level was largely comparable to that observed among breeding areas within each traditional subspecies group (Table 3 ). Differences in $P$ values associated with $D_{\text {mit }}$ and $D_{\text {mic }}$ at these two hierarchical levels may reflect the larger sample sizes (and associated power of tests) for subspecies-level comparisons in relation to comparisons of breeding areas within traditional subspecies groups.

\section{Discussion}

Least Tern genetic diversity and structure.-An important concern with regard to many endangered species is the loss of genetic diversity that results from population declines. Superficially, our analyses of Least Tern mtDNA and microsatellite data did not suggest that genetic diversity was low within the species. For example, our analyses revealed the presence of a large complement of mtDNA haplotypes (Table 2). Furthermore, though direct comparisons among studies can prove difficult when different loci are examined, measures of genetic diversity in Least Terns appear to exceed those observed in other tern species. Our microsatellite analyses (Table 1) revealed average numbers of alleles per locus, observed heterozygosities, and expected heterozygosities that were on par with or exceeded those found in colonies of Common Terns (S. hirundo; Sruoga et al. 2006). Also, the nucleotide diversity and total number of mtDNA control-region haplotypes in our analyses exceeded those previously noted in Sooty Terns (Onychoprion fuscatus = Sterna fuscata; Peck and Congdon 2004). 
Our more formal analyses of microsatellite data provided no conclusive evidence of pervasive past bottleneck events. Instead, the mtDNA data more frequently identified the signal of population expansions (Table 1). Of the 20 separate bottleneck analyses performed within breeding areas, significant results were obtained in only two cases from South Dakota and Kansas (SDMOR and KSKSR). These results are difficult to discern from random expectations and, moreover, contradict the allele frequency distributions at these sites that provided no evidence for prior bottlenecks. We note, however, that SDMOR and KSKSR are geographically proximate to one another (Fig. 1). Thus, if this pattern is not coincidental, our results may actually indicate that population bottlenecks have occurred in a small part of the Least Tern's geographic range. Recent population surveys have indicated moderate increases in population abundance since the mid-1980s and mid-1990s (for SDMOR and KSKSR, respectively; Lott 2006), which may reflect population increases following such bottleneck events. Additional detailed investigations within this region may be required to more conclusively establish this pattern. Because bottlenecks are generally detectable for only a few generations following the populationreduction event (Cornuet and Luikart 1996), such analyses should be performed in the near future if they are deemed to be worth pursuing for conservation and management purposes.

Our analyses indentified significant genetic structure among breeding areas. However, this pattern was primarily observed when we examined global differentiation by treating all 20 breeding areas as operational units of interest (Table 3). Significant isolationby-distance patterns were likewise noted across all breeding areas examined (Table 4). As a general rule, the strength of genetic structure will increase as the degree of natal and breeding-site fidelity increases within a species (i.e., minimizing gene-flow rates). Empirical field observations, however, indicate that nesting-site fidelity is variable in Least Terns. Using estimates based on banding and resight methods, natal philopatry ranges from $5 \%$ to $82 \%$, whereas breeding-site fidelity ranges from $28 \%$ to $97 \%$ (Atwood and Massey 1988, Massey and Fancher 1989, Boyd 1993, Renken and Smith 1995). These widely differing results among studies may depend on behavioral differences attributable to landscape type (i.e., coastal vs. interior rivers; Renken and Smith 1995) as well as the extent of banding and resight efforts. Traditionally, dispersal studies have focused on smaller scales (i.e., between colonies within traditional subspecies; Boyd 1993, Johnson and Castrale 1993, Lingle 1993). However, records exist of one juvenile banded at its natal site on the Gulf Coast of Texas (in the range of the Eastern traditional subspecies) that was later found nesting in Kansas (Boyd and Thompson 1985). Long-distance movements of individuals to new nesting locations (on the order of $300-1,000 \mathrm{~km}$ ) have also been reported (Renken and Smith 1995). Collectively, these types of findings may explain why little evidence of genetic structure was observed within each traditional subspecies (Table 3). Indeed, of the six analyses performed within a traditional subspecies, only one identified a significant pattern (the analysis of mtDNA data within the Interior breeding areas; Table 3). We note, however, that this specific finding may actually be spurious, because only a single pairwise contrast involving mtDNA from Interior breeding areas was significant at the $\alpha=0.05$ level (Appendix).

Within traditional subspecies, our analyses of isolation-bydistance patterns produced different results when mtDNA and microsatellite data were examined (Table 4). The microsatellites revealed slight but significant correlations between geographic distances and $D_{\text {mic }}$ within traditional subspecies; however, no comparable patterns existed for the mtDNA data. Because of its smaller effective population size, analyses of the mitochondrial genome may produce different patterns than those observed with nuclear markers solely because of differences in the effects of genetic drift. However, the different patterns may also indicate differences in dispersal tendencies between males and females (Chappel et al. 2004, Miller et al. 2005). Because of their maternal inheritance, genetic structure observed in mtDNA reflects female behavior patterns. By contrast, because they are biparentally inherited, genetic structure at microsatellite loci reflects the joint behavior of both sexes. Thus, the contrasting isolation-by-distance patterns observed in our analyses of microsatellites and mtDNA may indicate that male dispersal is limited compared with that of females. Distinguishing between these scenarios is difficult given our current data. Quantitative estimates of differentiation within each traditional subspecies were higher for mtDNA than for microsatellites, but significance levels were not appreciably different between marker types (Table 3 and Appendix). Sample-size limitations associated with mtDNA analyses prevented us from determining whether this was an artifact associated with limited sampling from a highly diverse, nondifferentiated group of populations, or whether the limited sampling provided insufficient power to detect true population differentiation. We note, however, that the minimal structure observed with mtDNA may, in this case, highlight female dispersal. Although sample sizes were also limited, previous genetic analyses of Least Terns have arrived at similar conclusions (Whittier et al. 2006). Because breeding pairs form on the nesting grounds (Thompson et al. 1997), the isolation-by-distance pattern observed only at microsatellite loci may therefore point to increased natal nesting-site fidelity of males in relation to females and corroborate previously documented patterns among the Laridae in general (Greenwood and Harvey 1982).

Least Tern subspecies.-Our analyses of mtDNA and microsatellite data did not provide conclusive support for the three traditional subspecies of Least Terns and reiterated results from two previous studies of the species (Thompson et al. 1992, Whittier et al. 2006). Although the number of haplotypes restricted to traditional subspecies was high (57), it is important to recognize that 36 of the 67 total detected haplotypes were observed only once and are therefore uninformative with respect to determining the degree of allele sharing between or among groups. Nonetheless, we note that $36-70 \%$ of individuals within each traditional subspecies shared haplotypes with individuals originating from another subspecies (Table 2). Consequently, mtDNA control-region sequences do not appear to provide support for traditional Least Tern subspecies designations (Amadon 1949, Patten and Unitt 2002).

Our STRUCTURE analyses also indicated little support for the existence of different subspecies, in that our results illustrated that the $K=1$ solution was most likely for the Least Tern microsatellite data set (Fig. 3). Superficially, this pattern conflicts with results of analyses based on $D_{\text {mic }}$, which detected low (but significant) differentiation among traditionally defined subspecies units (Table 3). This discrepancy may be attributable to STRUCTURE's inability to detect weak genetic structure or isolation-by-distance patterns (see sections 4.4 and 4.5 of STRUCTURE's documentation; 
Latch et al. 2006, Schwartz and McKelvey 2009). In our analyses, both of these factors may be relevant. In all comparisons between or among subspecies, values of $D_{\text {mic }}$ among subspecies were extremely low and on par with values observed within traditional subspecies units (Table 3). The significance of values associated with subspecies comparisons is most likely due to the larger sample sizes of operational units at this level than in analyses of breeding areas within each traditional subspecies. Furthermore, our Mantel tests suggested that the overarching structural pattern may reflect isolation-by-distance patterns of breeding areas across the Least Tern's range (Table 4). Thus, the observed significant differences among traditional subspecies may merely reflect the relatively large geographic distances between breeding areas found within the different traditionally defined subspecies (Fig. 1).

In addition to molecular data, morphological, behavioral, and geographic range information can also be used to determine whether a subspecies is "diagnosably distinct" (Mayr and Ashlock 1991, Winker and Haig 2010). However, previous studies that examined factors such as vocalizations, behavior, and morphological characteristics in Least Terns found little support for differences between traditional subspecies and concluded that any distinctions were arbitrary or clinal (Burleigh and Lowery 1942, Massey 1976, Thompson et al. 1992). One morphological study based on spectrophotometric analysis of feathers nominally provided validation for the three traditional subspecies (Johnson et al. 1998). If we assume that plumage differences are genetically associated, then spectrophotometric analysis may be used as genetic support of traditional Least Tern subspecies. However, Whittier et al. (2006) suggested that plumage differences may be related to other factors because the eumelanin that forms gray hues in Least Tern feathers can be influenced by environment or food sources (Welty and Baptista 1988).

Conservation implications.-Vignieri et al. (2006) argued that no single approach should be used as a "taxonomic litmus test" for taxa of concern. However, we would predict that "subspecies" that represent unique evolutionary entities should demonstrate congruent evidence of evolutionary distinctiveness. On the basis of our analyses, we cannot conclusively validate the traditional subspecies designations within Least Terns using our neutral mtDNA control-region or microsatellite data. Our findings can be used to consider a reevaluation of Least Tern subspecies by the AOU Committee on Taxonomy and Nomenclature. California, Interior, and Eastern Least Terns appear to exhibit high genetic connectivity among groups. However, genetic connectivity and demographic connectivity are not necessarily synonymous, because only a few migrants in each generation are needed to genetically homogenize disparate breeding populations, whereas the same level of movement cannot maintain demographically stable populations or permit recolonization of an extinct population (Wright 1931, 1940; Mills and Allendorf 1996).

Molecular tools have a demonstrated ability to identify evolutionarily divergent lineages. However, most studies, including ours, sample only a small part of the genome. Thus, neutral mtDNA control-region and microsatellite loci are not likely to reflect adaptive variation that may be relevant in different environments or for different life histories (McKay and Latta 2002). Although California, Interior, and Eastern Least Terns may continue to function as demographically independent populations, our findings emphasize the need for range-wide information on breeding-site fidelity and natal philopatry as well as an understanding of population-specific movements throughout the annual cycle in order to best plan for their future success.

\section{ACKNOWLEDGMENTS}

We thank C. Lott, R. Hurt, R. Boyd, M. McCollough, K. Stubbs, K. Kughen, T. Pover, J. Castrale, J. Boylan, R. Vanderlee, C. Kruse, P. Glass, H. Nass, R. Renken, K. Jones, S. Dinsmore, G. Pavelka, R. Boettcher, B. Winn, and P. Kelly for assistance and coordination of sample collection. We also thank T. Mullins, R. Bellinger, M. Schwartz, C. Funk, A. Liston, and K. Dugger for insightful discussion and helpful comments on the analysis and manuscript. For information on the Mid-Atlantic/New England/Maritimes Regional Working Group, see http://www.waterbirdconservation.org/manem. html. For information on the Southeast Regional Working Group, see http://www.waterbirdconservation.org/southeast_us.html. Support for this project was generously provided by the U.S. Geological Survey Forest and Rangeland Ecosystem Science Center and the U.S. Fish and Wildlife Service. Any use of trade, product, or firm names in this publication is for descriptive purposes only and does not imply endorsement by the U.S. Government.

\section{Literature Cited}

Amadon, D. 1949. The seventy-five percent rule for subspecies. Condor 51:250-258.

American Ornithologists' Union. 1957. Check-List of North American Birds, 5th ed. American Ornithologists' Union, Washington, D.C.

Atwood, J. L., AND B. W. MASSEy. 1988. Site fidelity of Least Terns in California. Condor 90:389-394.

Boyd, R. L. 1993. Site tenacity, philopatry, longevity, and population trends of Least Terns in Kansas and northwestern Oklahoma. Pages 196-205 in Proceedings, Missouri River and Its Tributaries: Piping Plover and Least Tern Symposium (K. F. Higgins and M. R. Brashier, Eds.). South Dakota State University, Brookings.

Boyd, R. L., AND B. C. THOMPSON. 1985. Evidence for reproductive mixing of Least Tern populations. Journal of Field Ornithology $56: 405-406$.

BRODKORB, P. 1940. New birds from southern Mexico. Auk 57:542549.

BueHLER, D. M., AND A. J. BAKER. 2003 Characterization of the Red Knot (Calidris canutus) mitochondrial control region. Genome 46:565-572.

Burger, J. 1984. Colony stability in Least Terns. Condor 86:61-67.

Burleigh, T. D., AND G. H. LOWERY. 1942. An inland race of Sterna albifrons. Occasional Papers of the Museum of Zoology, Louisiana State University 10:173-177.

Chappell, D. E., R. A. Van Den Bussche, J. Krizan, and B. Patterson. 2004. Contrasting levels of genetic differentiation among populations of wolves (Gulo gulo) from northern Canada revealed by nuclear and mitochondrial loci. Conservation Genetics 5:759-767.

Clement, M., D. Posada, and K. A. Crandall. 2000. TCS: A computer program to estimate gene genealogies. Molecular Ecology 9:1657-1659. 
Cornuet, J. M., and G. Luikart. 1996. Description and power analysis of two tests for detecting recent population bottlenecks from allele frequency data. Genetics 144:2001-2014.

DESJARDINS, P., AND R. MoraIs. 1990. Sequence and gene organization of the chicken mitochondrial genome. A novel gene order in higher vertebrates. Journal of Molecular Biology 212:599-634.

EXCOFfIER, L., G. LAVAL, AND S. SCHNEIDER. 2005. ARLEQUIN (version 3.0): An integrated software package for population genetics data analysis. Evolutionary Bioinformatics Online 1:47-50.

Fu, Y. X. 1997. Statistical tests of neutrality of mutations against population growth, hitchhiking and background selection. Genetics 147:915-925

Funk, C. W., T. D. Mullins, And S. M. Haig. 2007. Conservation genetics of Snowy Plovers (Charadrius alexandrinus) in the Western Hemisphere: Population genetic structure and delineation of subspecies. Conservation Genetics 8:1287-1309.

García, A., AND G. Ceballos. 1995. Reproduction and breeding success of California Least Terns in Jalisco, Mexico. Condor 97: 1084-1087.

Given, A. D., J. A. Mills, ANd A. J. BAKer. 2002. Isolation of polymorphic microsatellite loci from the Red-billed Gull (Larus novaehollandiae scopulinus) and amplification in related species. Molecular Ecology Notes 2:416-418.

Greenwood, P. J., And P. H. Harvey. 1982. The natal and breeding dispersal of birds. Annual Review of Ecology and Systematics 13:1-21.

Haig, S. M., E. A. Beever, S. M. Chambers, H. M. Draheim, B. D. Dugger, S. Dunham, E. Elliott-Smith, J. B. Fontaine, D. C. Kesler, B. J. Knaus, And others. 2006. Taxonomic considerations in listing subspecies under the U.S. Endangered Species Act. Conservation Biology 20:1584-1594.

Haig, S. M., AND J. D'Elia. 2010. Avian subspecies and the U.S Endangered Species Act. Pages 24-34 in Avian Subspecies (K. Winker and S. M. Haig, Eds.). Ornithological Monographs, no. 67.

Haig, S. M., E. D. Forsman, And T. D. Mullins. 2004. Subspecies relationships and genetic structure in the Spotted Owl. Conservation Genetics 5:683-705.

Hall, T. A. 1999. BioEdit: A user-friendly biological sequence alignment editor and analysis program for Windows 95/98/NT. Nucleic Acids Symposium Series 41:95-98.

HEDRICK, P. W. 2005. A standardized genetic differentiation measure. Evolution 59:1633-1638.

Johnson, N. K., J. V. Remsen, JR., And C. Cicero. 1998. Refined colorimetry validates endangered subspecies of the Least Tern. Condor 100:18-26.

JOHNSON, R. R., AND J. S. CASTRALE. 1993. Management of breeding Interior Least Terns in Indiana. Proceedings of the Indiana Academy Science 102:59-65.

JosT, L. 2008. $G_{\mathrm{ST}}$ and its relatives do not measure differentiation. Molecular Ecology 17:4015-4026.

KalinowsKi, S. T. 2005. HP-Rare: A computer program for performing rarefaction on measures of allelic diversity. Molecular Ecology Notes 5:187-189.

Kruse, C. D., K. F. Higgins, and B. A. Vander Lee. 2001. Influence of predation on Piping Plover, Charadrius melodus, and Least Tern, Sterna antillarum, productivity along the Missouri River in South Dakota. Canadian Field-Naturalist 115:480-486.
Latch, E., G. Dharmarajan, J. C. Glaubitz, and O. E. Rhodes, JR. 2006. Relative performance of Bayesian clustering software for inferring population substructure and individual assignment at low levels of population differentiation. Conservation Genetics 7:295-302.

Lesson, R. P. 1847. Histoire Naturelle des Colibris, Suive d'un Supplement a L'histoire Naturelles des Oiseaux-mouches. Bertrand, Paris.

Lewis, P. O., AND D. ZaYKin. 2001. Genetic Data Analysis: Computer program for the analysis of allelic data. Version 1.1. Free program distributed by the authors. [Online.] Available at http:// hydrodictyon.eeb.uconn.edu/people/plewis/software.php.

LingLE, G. R. 1993. Site fidelity and movements of Least Terns and Piping Plovers along the Platte River, Nebraska. Pages 189-191 in Proceedings, Missouri River and Its Tributaries: Piping Plover and Least Tern Symposium (K. F. Higgins and M. R. Brashier, Eds.). South Dakota State University, Brookings.

LotT, C. A. 2006. Distribution and abundance of the interior population of the Least Tern (Sterna antillarum), 2005: A review of the first complete range-wide survey in the context of historic and ongoing monitoring efforts. Dredging Operations and Environmental Research Program Technical Notes Collection, U.S. Army Corps Engineer Research and Development Center, Vicksburg, Mississippi.

Luikart, G., F. W. Allendorf, J.-M. Cornuet, And W. B. SherWIN. 1998. Distortion of allele frequency distributions provides a test for recent population bottlenecks. Journal of Heredity 89: 238-247.

MANTEL, N. 1967. The detection of disease clustering and a generalized regression approach. Cancer Research 27:209-220.

MarschaleK, D. A. 2005. California Least Tern breeding survey, 2004 season. Species Conservation and Recovery Program Report, 2005-01. California Department of Fish and Game, Habitat Conservation and Planning Branch, Sacramento, California.

Massey, B. W. 1976. Vocal differences between American Least Terns and the European Little Tern. Auk 93:760-773.

Massey, B. W., AND J. M. FANChER. 1989. Renesting by California Least Terns. Journal of Field Ornithology 60:350-357.

MAYR, E. 1942. Systematics and the Origin of Species. Columbia University Press, New York.

Mayr, E., AND P. D. AsHLock. 1991. Principles of Systematic Zoology, 2nd ed. McGraw-Hill, New York.

MCKAY, J. K., AND R. G. LATTA. 2002. Adaptive population divergence: Markers, QTL and traits. Trends in Ecology and Evolution 17:285-291

Mearns, E. 1916. Description of a new subspecies of the American Least Tern. Proceedings of the Biological Society of Washington 29:71.

Miller, M. P., S. M. Haig, and R. S. Wagner. 2005. Conflicting patterns of genetic structure produced by nuclear and mitochondrial markers in the Oregon slender salamander (Batrachoseps wrighti): Implications for conservation efforts and species management. Conservation Genetics 6:275-287.

Mills, L. S., AND F. W. Allendorf. 1996. The one-migrantper-generation rule in conservation and management. Conservation Biology 10:1509-1518.

Patten, M. A., And R. A. Erickson. 1996. Subspecies of the Least Tern in Mexico. Condor 98:888-890. 
Patten, M. A., And P. Unitt. 2002. Diagnosability versus mean differences of Sage Sparrow subspecies. Auk 119:26-35.

PeCK, D. R., And B. C. Congdon. 2004. Reconciling historical processes and population structure in the Sooty Tern Sterna fuscata. Journal of Avian Biology 35:327-335.

Phillimore, A. B., And I. P. F. Owens. 2006. Are subspecies useful in evolutionary and conservation biology? Proceedings of the Royal Society of London, Series B 273:1049-1053.

Pritchard, J. K., M. Stephens, and P. Donnelly. 2000. Inference of population structure using multilocus genotype data. Genetics 155:945-959.

Ramos-Onsins, S. E., AND J. Rozas. 2002. Statistical properties of new neutrality tests against population growth. Molecular Biology and Evolution 19:2092-2100.

RenKen, R. B., AND J. W. SMith. 1995. Interior Least Tern site fidelity and dispersal. Colonial Waterbirds 18:193-198.

Rozas, J., J. C. Sánchez-Delbarrio, X. Messeguer, and R. RozAS. 2003. DnaSP, DNA polymorphism analyses by the coalescent and other methods. Bioinformatics 19:2496-2497.

Schwartz, M. K., AND K. S. McKelvey. 2009. Why sampling scheme matters: The effect of sampling scheme on landscape genetic results. Conservation Genetics 10:441-452.

Sruoga, A., D. Butkauskas, P. Prakas, and A. Paulauskas. 2006. Evaluation of the genetic structure of the breeding Common Tern (Sterna hirundo) population by means of microsatellite markers. Biologija 1:47-52.

Szczys, P., C. R. Hughes, And R. V. Kesseli. 2005. Novel microsatellite markers used to determine the population genetic structure of the endangered Roseate Tern, Sterna dougallii, in Northwest Atlantic and Western Australia. Conservation Genetics 6:461-466.

TARR, C. L. 1995. Amplification and determination of mitochondrial control-region sequences in oscine passerines. Molecular Ecology 4:527-529.

Thompson, B. C., J. A. Jackson, J. Burger, L. A. Hill, E. M. Kirsch, and J. L. Atwood. 1997. Least Tern (Sterna antillarum). In The Birds of North America, no. 290 (A. Poole and F. Gill, Eds.). Academy of Natural Sciences, Philadelphia, and American Ornithologists' Union, Washington, D.C.

Thompson, B. C., M. E. SChmidt, S. W. Calhoun, D. C. Morizot, AND R. D. SLACK. 1992. Subspecific status of Least Tern populations in Texas: North American implications. Wilson Bulletin 104:244-262.

Tirard, C., F. Helfenstein, and E. Danchin. 2002. Polymorphic microsatellites in the Black-legged Kittiwake Rissa tridactyla. Molecular Ecology Notes 2:431-433.
U.S. Fish And Wildlife Service. 1980. California Least Tern recovery plan. U.S. Fish and Wildlife Service, Portland, Oregon.

U.S. Fish ANd Wildlife Service. 1985. Endangered and threatened wildlife and plants; interior population of Least Tern determined to be endangered. Federal Register 50:21784-21792.

U.S. Fish and Wildlife Service. 1990. Recovery plan for the interior population of the Least Tern (Sterna antillarum). U.S. Fish and Wildlife Service, Twin Cities, Minnesota.

U.S. Fish and Wildlife Service and National Marine FishERIES SERVICE. 1996. Policy regarding the recognition of distinct vertebrate population segments under the Endangered Species Act. Federal Register 61:4721-4725.

van Rossem, A. J., and The Marquess Hachisuka. 1937. A further report on birds from Sonora, Mexico, with description of two new races. Transactions of the San Diego Society of Natural History 8:321-336.

Vignieri, S. N., E. M. Hallerman, B. J. Bergstrom, D. J. Hafner, A. P. Martin, P. Devers, P. Grobler, and N. Hitt. 2006. Mistaken view of taxonomic validity undermines conservation of an evolutionarily distinctive mouse: A response to Ramey et al. 2005. Animal Conservation 9:237-243.

WAKELEY, J. 1996. The excess of transitions among nucleotide substitutions: New methods of estimating transition bias underscore its importance. Trends in Ecology and Evolution 11:158-162.

Welty, J. C., AND L. F. Baptista. 1988. The Life of Birds, 4th ed. Saunders College Publishing, Philadelphia.

Wenink, P. W., A. J. Baker, and M. G. J. Tilanus. 1994. Mitochondrial control-region sequences in two shorebird species, the Turnstone and the Dunlin, and their utility in population genetic studies. Molecular Biology and Evolution 11:22-31.

WhitLOCK, M. C. 2005. Combining probability from independent tests: The weighted $Z$-method is superior to Fisher's approach. Journal of Evolutionary Biology 18:1368-1373.

Whittier, J. B., D. M. Leslie, JR., ANd R. A. Van Den Bussche. 2006. Genetic variation among subspecies of Least Tern (Sterna antillarum): Implications for conservation. Waterbirds 29:176-184.

WiLson, E. O., AND W. L. Brown, JR. 1953. The subspecies concept and its taxonomic application. Systematic Zoology 2:97-111.

WINKER, K., AND S. M. HAIG, EDS. 2010. Avian subspecies. Ornithological Monographs, no. 67.

Wright, S. 1931. Evolution in Mendelian populations. Genetics 16:97-159.

WRIGHT, S. 1940. Breeding structure of populations in relation to speciation. American Naturalist 74:232-248.

Associate Editor: J. P. Dumbacher 


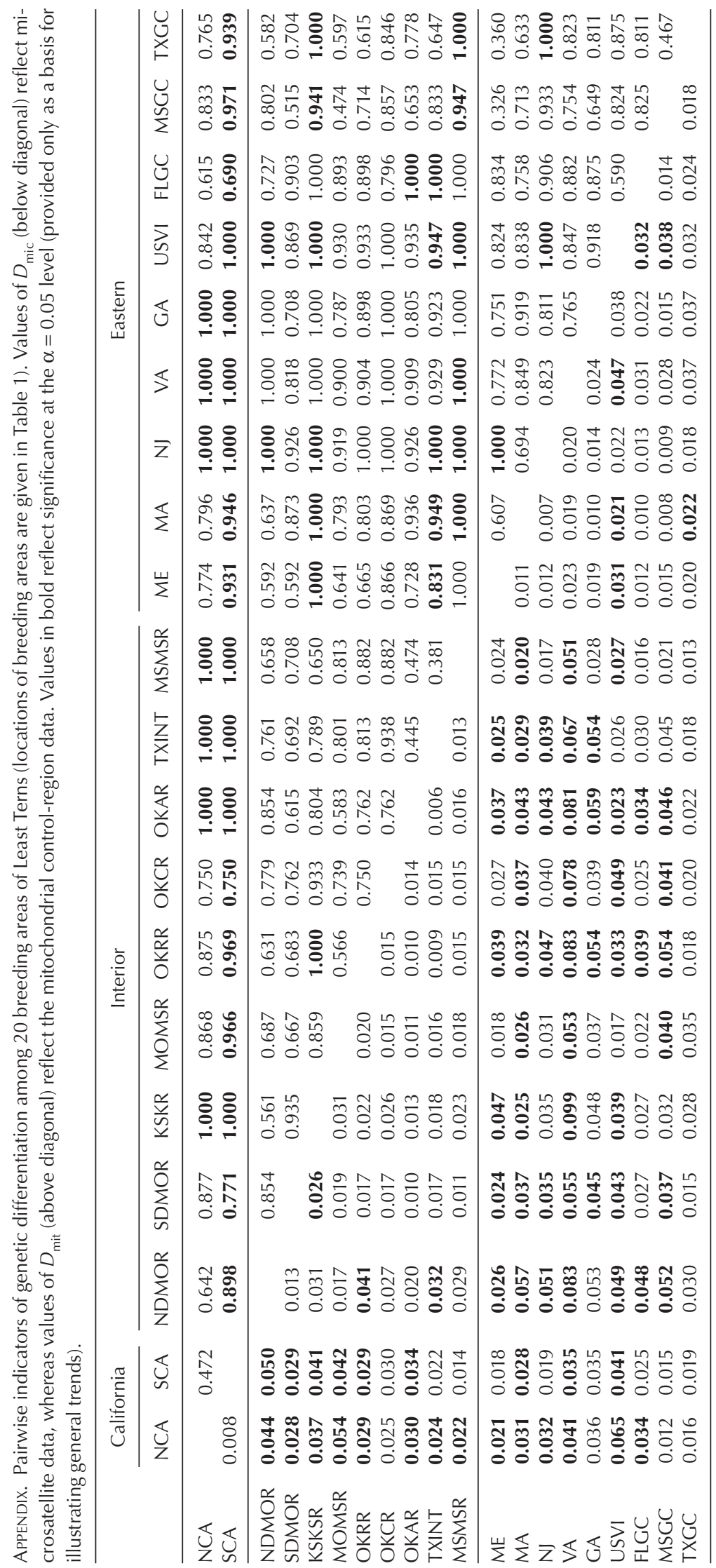

